\title{
Risk factors for new-onset diabetes mellitus after kidney transplantation (NODAT): a Brazilian single center study
}

Camila Lima', Amanda Grden', Thelma Skare',

Paulo Jaworski', Renato Nisihara ${ }^{1,2}$

\begin{abstract}
Objectives: This study aims to verify the new-onset diabetes after kidney transplant (NODAT) incidence in recipients within 1 year after kidney transplantation from a single center in Southern Brazil and to assess the associated conditions. Subjects and methods: A retrospective study of 258 postrenal transplant patients was performed. Demographic (gender, age, ethnic background) and clinical (origin of graft, associated infections, body mass index (BMI) at transplant time and 6 and 12 months after, causes of renal failure, and comorbidities) data were analyzed. All patients were on tacrolimus, mycophenolate mofetil, and prednisone treatment. Patients with and without NODAT were compared. Results: A NODAT incidence of $31.2 \%$ was noted 1 year post transplantation. In the univariate analysis, patients with NODAT were older $(p=0.001)$, mostly had African-American ethnic background $(\mathrm{p}=$ $0.02)$, and had renal failure secondary to high blood pressure (HBP) $(p=0.001)$. The group of patients with NODAT also had more incidence of post-transplant HBP $(p=0.01)$, heart failure $(p=0.02)$, and dyslipidemia $(p=0.001)$. Logistic regression showed that African-American ethnic background, posttransplant HBP, and dyslipidemia were independently associated with NODAT. Conclusion: This study shows a NODAT incidence that is greater in patients with African-American ethnic background and that is associated with HBP and dyslipidemia. Arch Endocrinol Metab. 2018;62(6):597-601
\end{abstract}

Keywords

New-onset diabetes after transplantation (NODAT); diabetes mellitus; renal transplant; calcineurin inhibitors
1 Universidade Evangélica, Departamento de Medicina, Curitiba, PR, Brasil

2 Universidade Positivo, Departamento de Medicina, Curitiba, PR, Brasil

Correspondence to: Renato Nisihara Departamento de Medicina, Rua Padre Agostinho, 2770 80730-000 - Curitiba, PR, Brasil renatonisihara@gmail.com

Received on Aug/5/2017 Accepted on Dec/13/2017

DOI: $10.20945 / 2359-3997000000084$

\section{INTRODUCTION}

$\mathrm{N}$ ew-onset diabetes after transplant, or NODAT, is one of the major complications after solid organ transplantation $(1,2)$. There is a five- to six-fold higher incidence of new-onset diabetes mellitus (DM) in the first year post kidney transplantation in comparison to waiting-listed patients (3). This complication is considered to lead to graft failure and to promote cardiovascular disease, one of the main causes of death in transplant recipient (4). A large meta-analysis has shown that NODAT is present in $2 \%-50 \%$ of patients, 1 year after the transplant procedure (5).

The pathophysiology of NODAT closely mimics type 2 DM: insulin resistance and insulin hyposecretion develop in both situations. Nevertheless, in NODAT, insulin hyposecretion seems to be a crucial determining factor in glucose tolerance deterioration (4).
Several risk factors were known to be associated with NODAT, such as ethnic background, family history of diabetes, sedentary lifestyle, high body mass index (BMI), and cytomegalovirus and hepatitis $\mathrm{C}$ virus (HCV) infection. A high dose of glucocorticoids and the use of immunosuppressive regimen with calcineurin inhibitors may also be associated with this condition (6-8). Numakura and cols. (9) found that genetic factors such as certain vitamin D receptor haplotypes lead to increased risk of NODAT. Kim and cols. (10) found that Toll-like receptor (TLR)-4 and TLR-6 gene polymorphisms were significantly associated with NODAT, showing that the innate immune system and inflammation via TLR activation may have an important role in the pathogenesis of this complication. The results of some studies indicate that several genes, such as interleukins, transcription factor 7 -like 2 , solute 
carrier family 30 (zinc transporter), member 8 genes (SLC30A8), matrix metalloproteinases (MMPs), and chemokine (C-C motif) ligand 5 (CCL5) genes, were related with the development of NODAT (11-15).

Genetic background may influence the prevalence of NODAT in different populations (6). The increased survival of renal transplant patients requires adequate attention as its complication may interfere with patients' survival and quality of life $(16,17)$. Aiming to know the prevalence of NODAT and its risk factors in the region, a cohort of kidney transplant recipients from Southern Brazil were studied.

\section{SUBJECTS AND METHODS}

This retrospective study was approved by the local Committee of Ethics in Research (56934016.4.0000.0103). Charts of kidney transplant patients from a single center, a university evangelical hospital, located in the city of Curitiba, Paraná, Brazil, registered from July to December 2015, were reviewed for epidemiological, clinical, and treatment profile.

Patients under 18 years of age, those with DM prior to transplantation, those who had first-degree relatives with DM, and those who had used immunobiological drugs or had graft rejection were excluded.

The study sample included 258 patients (141/268 or $52.6 \%$ males, with median age of 43 years; range 18 75 years). All patients were on standard treatment, with prednisone, mycophenolate mofetil, and tacrolimus, which is determined by the Brazilian Health Ministry, Ordinance 1.168, in 2004.

The following data of all patients were reviewed retrospectively for 12 months: BMI prior to transplantation and six and twelve months post transplantation, causes of renal failure prior to transplantation, graft origin (either from deceased or living donor), and occurrence of hepatitis $\mathrm{C}$ and $\mathrm{CMV}$ infections. The diagnosis of DM was made according to the American Diabetes Association, through the analysis of three altered values of blood glucose, which was done by the transplant doctor and was registered in the patient medical record 12 months after transplantation (18).

The obtained data was collected in frequency and contingency tables. The epidemiological and clinical profiles between patients with and without NODAT were compared using the Fisher exact test and chisquare tests for nominal data and unpaired t-test and Mann-Whitney test for numeric data. To assess variables independently, logistic regression was used. The significance level adopted was $5 \%$.

\section{RESULTS}

The description of clinical, epidemiological, and treatment data of kidney transplant patients being studied are shown in Table 1.

Only three patients had HCV infection. In this sample, the NODAT incidence was $31.2 \%$.

Table 2 shows the results obtained between patients with and without NODAT were compared. It is noticeable that elder patients, African-American background patients, and the group with hypertension and dyslipidemia had a higher NODAT incidence. Patients with NODAT also experience more hypertension and less chronic glomerulonephritis, which are causes of renal failure that required transplantation.

When all variables with $\mathrm{p}<0.1$ were studied through logistic regression, it was found that African-American ethnic background $(\mathrm{p}=0.03$; OR $=2.08 ; 95 \% \mathrm{CI}=$ 1.05-4.14), dyslipidemia ( $\mathrm{p}=0.03 ; \mathrm{OR}=2.08 ; 95 \% \mathrm{CI}$ $=1.09-5.12)$, and hypertension $(\mathrm{p}=0.04 ; \mathrm{OR}=4.7$; $95 \%$ CI $=1.04-21.5)$ were independently associated with NODAT.

\section{DISCUSSION}

In the present study, which included 258 renal post transplanted recipients, all in the same therapeutic regimen, there was a NODAT incidence of $31.2 \%$ in the first year after the transplant procedure. It is noteworthy that individuals with DM in the first-degree relatives in the sample were excluded, so the possible occurrence of a common type $2 \mathrm{DM}$ was minimized. In addition, it was observed that NODAT was independently associated with factors such as African-American background, arterial hypertension, and dyslipidemia.

Other authors have found that a myriad of factors affect the development of NODAT, such as high BMI, the use of calcineurin inhibitors and corticosteroids, old age, and cytomegalovirus (CMV) and hepatitis C infection (1). BMI alone was not linked to the appearance of this complication in the sample. However, the sample's mean BMI ranged from 24 to $26 \mathrm{~kg} / \mathrm{m}^{2}$ which is close to the accepted normal range. Therefore, obesity, which is widely linked to DM, was 
Table 1. Clinical, epidemiological and treatment data of kidney transplanted patients $(n=258)$

\begin{tabular}{|c|c|c|c|}
\hline Variable & & n & (\%) or central tendency \\
\hline \multirow{3}{*}{$\begin{array}{l}\text { Ethnic background } \\
\text { (auto declared) }\end{array}$} & Caucasians & 209 & $35 ; 78.6$ \\
\hline & Asian & 1 & 0.3 \\
\hline & Afro descendants & 53 & 20.9 \\
\hline \multirow[t]{8}{*}{ Causes of renal failure } & Chronic glomerulonephritis & 125 & 51.9 \\
\hline & Hypertension & 43 & 16.6 \\
\hline & Polycystic kidney disease & 21 & 8.1 \\
\hline & Pyelonephritis and litiasis & 12 & 4.6 \\
\hline & IgA nephropathy & 11 & 4.2 \\
\hline & Others & 37 & 14.6 \\
\hline & 6 months post transplantation & & $24.2(22.2-28.5)$ \\
\hline & 12 months post transplantation & & $26.1(23.1-29.7)$ \\
\hline \multirow[t]{4}{*}{ Graft type } & Cadaveric & 121 & 46.8 \\
\hline & Living donor (relative) & 98 & 37.9 \\
\hline & Living donor (not relative) & 37 & 14.3 \\
\hline & Unknown & 2 & 0.7 \\
\hline \multirow[t]{4}{*}{ Co-morbidities } & Arterial hypertension & 229 & 87.5 \\
\hline & Dyslipidemia & 38 & 14.3 \\
\hline & Ischemic heart disease & 10 & 3.8 \\
\hline & Heart failure & 3 & 1.1 \\
\hline
\end{tabular}

BMI: body mass index; CMV: cytomegalovirus.

Table 2. Comparison of renal transplanted patients according to presence or not of NODAT (New Onset Diabetes After Transplantation)

\begin{tabular}{|c|c|c|c|}
\hline & $\begin{array}{l}\text { With NODAT } \\
31.2 \%\end{array}$ & $\begin{array}{c}\text { Without NODAT } \\
\quad 68.8 \%\end{array}$ & $\mathbf{P}$ \\
\hline Median age (years) & $48(37-56)$ & $41(26-51)$ & 0.001 \\
\hline Ethnic background & $\begin{array}{c}\text { Afro descend }-30.2 \% \\
\text { Caucasian }-69.7 \%\end{array}$ & $\begin{array}{l}\text { Afro descend - } 17.5 \% \\
\text { Caucasian }-82.4 \%\end{array}$ & $0.02^{*}$ \\
\hline Male gender & $62 \%$ & $52.8 \%$ & 0.17 \\
\hline Causes of renal failure & $\begin{array}{c}\text { Glomerulonephritis }-35.8 \% \\
\text { Hypertension }-28.2 \% \\
\text { Others }-35.8 \%\end{array}$ & $\begin{array}{c}\text { Glomerulonephritis - 56.6\% } \\
\text { Hypertension }-12.0 \% \\
\text { Others }-31.3 \%\end{array}$ & $0.001^{\star \star}$ \\
\hline Graft donor & $\begin{array}{c}\text { Deceased }-53.1 \% \\
\text { Living related }-36.7 \% \\
\text { Living not related }-10.1 \%\end{array}$ & $\begin{array}{c}\text { Decesead }-44.7 \% \\
\text { Living related }-15.6 \% \\
\text { Living not related }-39.2 \%\end{array}$ & 0.34 \\
\hline $\begin{array}{l}\text { Median BMI }\left(\mathrm{kg} / \mathrm{m}^{2}\right) \\
\text { pre transplant }\end{array}$ & $24.9(22.0-27.9)$ & $24.5(21.5-28.1)$ & 0.49 \\
\hline $\begin{array}{l}\text { Mean BMl }\left(\mathrm{kg} / \mathrm{m}^{2}\right) \\
6 \text { months post-transplant }\end{array}$ & $25.5 \pm 4.1$ & $25.4 \pm 4.2$ & 0.78 \\
\hline $\begin{array}{l}\text { Mean BMl }\left(\mathrm{kg} / \mathrm{m}^{2}\right) \\
12 \text { months post-transplant }\end{array}$ & $26.4 \pm 4.7$ & $26.3 \pm 4.5$ & 0.89 \\
\hline Associated arterial hypertension & $97.4 \%$ & $85.6 \%$ & $0.01^{\#}$ \\
\hline Associated dyslipidemia & $25.3 \%$ & $9.7 \%$ & $0.001^{\# \#}$ \\
\hline Associated heart failure & $3.7 \%$ & 0 & $0.02^{\S}$ \\
\hline Associated coronary insufficiency & $5.06 \%$ & $9.7 \%$ & 0.50 \\
\hline CMV infection & $1.2 \%$ & $4.02 \%$ & 0.44 \\
\hline
\end{tabular}

BMI: body mass index; CMV: cytomegalovirus.

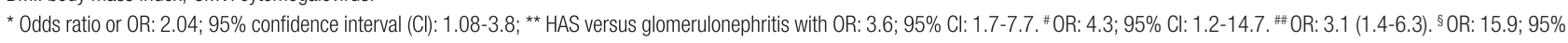
Cl: 0.8-313.1. 
underrepresented in the sample. This may explain the diversity of the results found. Additionally, CMV infection could not be associated with NODAT in this study, considering the very low incidence of infection in patients. The same occurs with HCV infection. However, literature concerning $\mathrm{HCV}$ infection and NODAT is ambiguous, with some authors supporting higher prevalence of these findings (19) and others denying it $(20,21)$. In this sample, two of three patients with HCV infection developed DM.

NODAT's association with African-American background was also described by other authors (19). This association was also observed in the Brazilian sample, regardless of the fact that Brazilian people have a highly mixed ethnic background.

Tacrolimus is considered one of the main NODAT causes, (22) and all of the patients were receiving it. A calcineurin inhibitor has been considered the cornerstone of immunosuppressive regimens in renal transplant (22). It inhibits T-cell activation, thereby inhibiting interleukin-2 syntheses, and leads to a failure of T-cell clonal expansion (23). Several authors have shown that patients treated with tacrolimus have higher NODAT incidence when compared to those who were treated with cyclosporine $(1,24)$. Nonetheless, tacrolimus was shown to be superior to cyclosporine in terms of patient mortality, graft loss, and hypertension development (24).

The mechanism involved in tacrolimus-induced NODAT includes diminished insulin secretion, as calcineurin is expressed in pancreas $\beta$ cells. This medication disrupts mitochondrial permeability, causes inhibition of NFAT transcription factor, and targets cAMP-responsive element-binding protein transcriptional coactivator (3). In addition, it inhibits glucose uptake from muscular cells and adipocytes (3). Hypomagnesemia is one of the proposed mechanisms for calcineurin-associated glucose intolerance, due to magnesium which is essential for glucose transport and pancreatic insulin secretion, and is involved in the postreceptor insulin signaling $(25)$.

NODAT is associated with lower survival of transplanted recipients, and it is an independent risk factor linked to graft failure (22). Furthermore, classic DM complications are seen in patients with NODAT such as peripheral neuropathy, ketoacidosis, hyperosmolar coma, and even biopsy-proven diabetic nephropathy $(22,26)$. Serum creatinine levels are significantly higher in patients with NODAT compared to those without it after 5 years of transplantation
$(22,26)$. All these complications lead to increased mortality, mainly due to cardiovascular events $(22,26)$. Cosio and cols. (27) demonstrated that the 5-year cumulative incidence of cardiovascular events was correlated with fasting glucose levels seen 1 year after transplantation. It was found that a higher rate of hypertension and dyslipidemia in the NODAT sample is known to be a risk factor for atherosclerotic disease and cardiovascular events.

This is a retrospective study, which is also considered one of the limitations. It is also possible that the occurrence of NODAT would be higher in longer periods of observation.

In conclusion, this study shows a higher NODAT incidence in kidney transplant recipients with AfricanAmerican ethnic background. Moreover, NODAT is associated with higher blood pressure levels and dyslipidemia in all transplant recipients, regardless of the ethnic background. Prospective and multicentric studies may be useful to better understand and prevent NODAT.

Funding of sources: none.

Disclosure: no potential conflict of interest relevant to this article was reported.

\section{REFERENCES}

1. Yu H, Kim H, Baek CH, Baek SD, Jeung S, Han DJ, et al. Risk factors for new-onset diabetes mellitus after living donor kidney transplantation in Korea - A retrospective single center study. BMC Nephrol. 2016;17(1):106.

2. Räkel $A$, Karelis $A D$. New-onset diabetes after transplantation: risk factors and clinical impact. Diabetes Metab. 2011;37(1):1-14.

3. Chakkera HA, Kudva $Y$, Kaplan B. Calcineurin Inhibitors: Pharmacologic mechanisms impacting both insulin resistance and insulin secretion leading to glucose dysregulation and diabetes mellitus. Clin PharmacolTher. 2017;101(1):114-20.

4. Davidson J, Wilkinson A, Dantal J, Dotta F, Haller H, Hernández D, et al. New-onset diabetes after transplantation: 2003 International consensus guidelines. Proceedings of an international expert panel meeting. Barcelona, Spain, 19 February 2003. Transplantation. 2003 May 27;75(10 Suppl):SS3-24.

5. Montori VM, Basu A, Erwin PJ, Velosa JA, Gabriel SE, Kudva YC. Posttransplantation diabetes: a systematic review of the literature. Diabetes Care. 2002;25(3):583-92.

6. Kurzawski M, Dziewanowski K, Łapczuk J, Wajda A, Droździk M. Analysis of common type 2 diabetes mellitus genetic risk factors in new-onset diabetes after transplantation in kidney transplant patients medicated with tacrolimus. Eur J Clin Pharmacol. 2012;68(12):1587-94.

7. Kasiske BL, Snyder JJ, Gilbertson D, Matas AJ. Diabetes mellitus after kidney transplantation in the United States. Am JTransplant. 2003;3(2):178-85.

8. Van Hooff JP, Christiaans MH, van Duijnhoven EM. Tacrolimus and posttransplant diabetes mellitus in renal transplantation. Transplantation. 2005;79(11):1465-9. 
9. Numakura K, Satoh S, Tsuchiya N, Horikawa Y, Inoue T, Kakinuma $\mathrm{H}$, et al. Clinical and genetic risk factors for posttransplant diabetes mellitus in adult renal transplant recipients treated with tacrolimus. Transplantation. 2005;80(10):1419-24.

10. Kim JS, Kim SK, Park JY, KimYG, Moon JY, Lee SH, et al. Significant association between toll-like receptor gene polymorphisms and posttransplantation diabetes mellitus. Nephron. 2016;133(4): 279-86.

11. Bamoulid J, Courivaud C, Deschamps M, Mercier P, Ferrand C, Penfornis A, et al. IL-6 promoter polymorphism-174 is associated with new-onset diabetes after transplantation. J Am Soc Nephrol. 2006;17(8):2333-40.

12. Kim YG, Ihm CG, Lee TW, Lee SH, Jeong KH, Moon JY, et al. Association of genetic polymorphisms of interleukins with newonset diabetes after transplantation in renal transplantation. Transplantation. 2012 May 15;93(9):900-7.

13. Kang ES, Kim MS, Kim YS, Kim CH, Han SJ, Chun SW, et al. A polymorphism in the zinc transporter gene SLC30A8 confers resistance against posttransplantation diabetes mellitus in renal allograft recipients. Diabetes. 2008;57(4):1043-7.

14. Jeong K, Moon J, Chung J, Kim YH, Lee TW. Significant associations between CCL5 gene polymorphisms and posttransplantational diabetes mellitus in Korean renal allograft recipients. Am J Nephrol. 2010;32(4):356-61.

15. Ong S, Kang SW, Kim YH, KimTH, Jeong KH, Kim SK, et al. Matrix metalloproteinase gene polymorphisms and new-onset diabetes after kidney transplantation in Korean renal transplant subjects. Transplant Proc. 2016;48(3):858-63.

16. Aktas A. Transplanted kidney function evaluation. Semin Nucl Med. 2014;44(2):129-45.

17. D'Addio F, Vergani A, Di Fenza R, Tezza S, Bassi R, Fiorina P. Novel immunological aspects of pediatric kidney transplantation. G Ital Nefrol. 2012;29(1):44-8.
18. American Diabetes Association. Diagnosis and classification of diabetes mellitus. Diabetes Care. 2007;30 (suppl 1):s42-7.

19. Shah T, Kasravi A, Huang E, Hayashi R, Young B, Cho YW, et al. Risk factors for development of new-onset diabetes mellitus after kidney transplantation. Transplantation. 2006;82(12):1673-6.

20. Kishi $Y$, Sugawara $Y$, Tamura S, Kaneko J, Matsui $Y$, Makuuchi M. New-onset diabetes mellitus after living donor liver transplantation: possible association with hepatitis C. Transplant Proc. 2006;38(9):2989-92.

21. Tueche SG. Diabetes mellitus after liver transplant new etiologic clues and cornerstones for understanding. Transplant Proc. 2003;35(4):1466-8.

22. Guitard J, Rostaing L, Kamar N. New-onset diabetes and nephropathy after renal transplantation. Contrib Nephrol. 2011;170:247-55.

23. Shrestha BM. Two Decades of Tacrolimus in Renal Transplant: Basic Science and Clinical Evidences. Exp Clin Transplant. 2017;15(1):1-9.

24. Muduma G, Saunders R, Odeyemi I, Pollock RF. Systematic review and meta-analysis of tacrolimus versus ciclosporin as primary immunosuppression after liver transplant. PLoS One. 2016;11(11):e0160421.

25. Sinangil A, Celik V, Barlas S, Sakaci T, KocY, BasturkT, et al. NewOnset Diabetes After Kidney Transplantation and Pretransplant Hypomagnesemia. Prog Transplant. 2016;26(1):55-61.

26. Miles AM, Sumrani N, Horowitz R, Homel P, Maursky V, Markell MS, et al. Diabetes mellitus after renal transplantation: as deleterious as non- transplant- associated diabetes? Transplantation. 1998;65(3):380-4.

27. Cosio FG, Kudva Y, van der Velde M, Larson TS, Textor SC, Griffin $M D$, et al. New onset hyperglycemia and diabetes are associated with increased cardiovascular risk after kidney transplantation. Kidney Int. 2005;67(6):2415-21. 